\title{
PLASMA CELL AND B CELL-TARGETED TREATMENTS FOR USE IN ADVANCED MULTIPLE SCLEROSIS
}

David Baker ${ }^{1}$, Benjamin M. Jacobs ${ }^{1}$, Sharmilee Gnanapavan ${ }^{1,2}$, Klaus Schmierer ${ }^{1,2}$, Gavin Giovannoni ${ }^{1,2}$

1. BartsMS, Blizard Institute, Barts and the London School of Medicine and Dentistry, Queen Mary University of London, London E1 2AT, United Kingdom.

2. Clinical Board:Medicine (Neuroscience), The Royal London Hospital, Barts Health NHS Trust, London E1 1BB, United Kingdom

Running head: Targeting B cells to control autoimmunity

Corresponding author: Prof. David Baker; BartsMS, Blizard Institute, Barts and the London School of Medicine and Dentistry, Queen Mary University of London, 4 Newark Street, London E1 2AT. Tel: +442078822485; Fax: +442078822180; Email: david.baker@qmul.ac.uk 


\section{ABSTRACT}

There is increasing evidence that agents that target peripheral B cells and in some instances plasma cells can exhibit marked effects on relapsing multiple sclerosis. In addition, B cells, including plasma cells, within the central nervous system compartment are likely to play an important role in disease progression in both relapsing and progressive MS. However, current B cell-targeting antibodies may not inhibit these, because of poor penetration into the central nervous system and often oligoclonal bands of immunoglobulin persist within the cerebrospinal fluid despite immunotherapy. Through targeting B cells and plasma cells in the CNS, it may be possible to obtain additional benefit above simple peripheral depletion of $B$ cells. As such there are a number of inhibitors of $B$ cell function and $B$ cell depleting agents that have been developed for myeloma and B cell leukaemia and lymphoma, which could potentially be used off-label or as an experimental treatment for advanced (progressive) MS.

Keywords: B cells, immunotherapy, multiple sclerosis, progressive multiple sclerosis.

\section{HIGHLIGHTS}

- Peripheral B cell responses have been targeted to inhibit active/relapsing multiple sclerosis.

- Inhibition of advance (progressive) multiple sclerosis may be achieved by targeting B cell responses in the CNS.

- Agents exist that could be used to target such B cell responses and could be used to show benefit 


\section{INTRODUCTION}

Although multiple sclerosis (MS) is historically considered to be a T cell-mediated autoimmune disease of the central nervous (CNS), response to therapy has demonstrated that inhibitors of $B$ cell activity are potent inhibitors of disease (Stüve et al. 2005; Reviewed in Baker et al. 2017 and Baker et al. 2018). There is evidence that all current effective disease-modifying therapies for relapsing MS interfere with B cell function, either through depletion of B cell numbers or inhibition of effector functions, in a manner that reflects their level efficacy in relapsing MS. (Gandoglia et al. 2017; Storek et al 2004; Dooley et al. 2015; Reviewed in Baker et al. 2017; Ceronie et al. 2018). Strikingly, for any given disease-modifying agent, the degree of memory $B$ cell inhibition correlates well with disease-modifying efficacy (Dooley et al. 2015; Reviewed in Baker et al. 2017). Indeed, continuous depletion of CD20-expressing B cell subsets has led to the licencing of the first agent to treat both relapsing and primary progressive MS (Montalban et al. 2017; Hauser et al. 2017; Mulero et al. 2018).

In addition to playing a significant role in driving relapsing biology, B cells are likely to play an important role in disease progression, both in the context of relapsing and primary and secondary progressive disease, which have active components driven by the adaptive-immune response entering the CNS (Lublin 2014) and non-active disease-associated neurodegenerative components probably driven by glial-derived immune responses that may be poorly-responsive to current disease modifying treatments (Lublin 2014; Montalban et al. 2017; Al Salama 2019; Reviewed in Baker et al. 2018).

However, B-cell depleting monoclonal antibodies may not effectively target the B cell compartment with the CNS, as antibodies penetrate the CNS poorly (Tran et al. 2014; Reviewed in Baker et al. 2018) and oligoclonal bands (OCB) often persist despite therapy (Reviewed in Pryce \& Baker 2018 and Baker et al. 2018). Therefore, by targeting B cells and plasma cells in the CNS (Figure 1), it may be possible to obtain additional benefit above simple peripheral depletion of B cells. As such, there are a number of inhibitors of B cell function and B cell depleting agents (Figure 1) that have been developed for myeloma and B cell leukaemia and lymphoma, which could be used off-label or as an experimental treatment for progressive MS, given that lumbar puncture and intraventricular delivery of intrathecal CD20-depleting antibodies has so far been disappointing for targeting B cell responses within the CNS (Topping et al. 2016; Komori et al. 2016; Bergman et al. 2016).

\section{ANTIBODIES}

Monoclonal antibodies provide the most specific way of targeting particular B cell subsets. Indeed, both CD19 and CD20-specific antibodies have been found to inhibit relapsing MS (Reviewed in Baker et al. 2017 and Baker et al. 2018). However, as these markers are not expressed by plasma cells, it demonstrates that they and immunoglobulin are not essential for disease activity (Ireland et al. 2012; Baker et al. 2017a). Whilst these target the mechanisms driving relapsing disease (Hauser et al. 2017; Reviewed in Baker et al. 2018), CD20-depleting 
antibodies also can inhibit, at least active, primary progressive MS (Hawker et al. 2009; Montalban et al. 2017). This can be targeted by ocrelizumab and off-label rituximab and other antibodies in development), such as ofatumumab ((Du et al. 2017; Bar-Or et al. 2018). However, the action against progressive MS may be secondary to inhibition of active disease, rather than via a direct neuroprotective effect (Hawker et al. 2009; Castillo-Trivino et al. 2013). Indeed, this may not be surprising as monoclonal antibodies fail to significantly enter the CNS (Figure 1), CD20-depleting antibodies exhibit limited direct killing of B cells in the CNS (Topping et al. 2016; Komori et al. 2016), do not kill plasma cells (Sabatino et al. 2016) and do not initially affect immunoglobulin levels and OCB within the cerebrospinal fluid (Castillo-Trivino et al. 2013; Sabatino et al. 2016; Studer et al. 2014). Although, there are antibody agents that can target plasma cells, as used in myeloma such as: indatuximab (CD138-specific)-ravtansine; lorvotuzumab (CD56-specific)-mertansine, CD38 (daratuumumab) and CD27+, memory B cells such as varlilumab (Robart \& Robart 2016; Schönfeld et al. 2017; Burris et al. 2017), given the poor penetration of antibodies (99.9\% excluded. Kikuchi et al. 2004; Tran et al. 2014) across the blood-brain barrier and the limited killing capacity of intrathecal-administered antibody (Topping et al. 2016; Komori et al. 2016), probably due to lack of sufficient effector mechanisms for complement fixation and/or antibody dependent cellular cytotoxicity within the CNS (Komori et al. 2016), use of antibodies does not appear to be the most optimised method to target $B$ cells within the CNS. However, CD20-depletion could be a base on which to add neuroprotection and repair activity as the drug may have immune-reconstitution therapy potential (Baker et al. 2017). However, B cells form a central part of immunity. As such, continuous B cell depletion is associated with reductions in immunoglobulin levels and an increased risk of infection that is going to accumulate with time (Hauser et al. 2017; Giovannoni 2018). These risks can be significant, and is of interest that the development of ocrelizumab was terminated in other CD20responsive autoimmunities because of infection-related fatalities adversely affecting the risk: benefit balance (Harigai et al. 2012; Emery et al. 2014). However, it may be possible to achieve benefit from pulsed therapies to avoid problems with continuous immunosuppression (Baker et al. 2017).

\section{SMALL MOLECULE IMMUNE INHIBITORS}

$B$ cells have a more rapid turnover than $T$ cells and rapidly die in vitro and are susceptible to cytostatic agents that kill cells during DNA replication (Baker et al. 2017a). Therefore, B cells including both regulatory and effector $B$ cells are particularly sensitive to cytostatic agents (Minagawa et al. 1987; O'Neill et al. 1992; Baker et al. 2017a). In animals this can mean that $B$ cell therapy can have distinct and opposing activity, dependent on timing of treatments (Minagawa et al. 1987; O'Neill et al. 1992; Sefia et al. 2017). Similarly B cell immunotherapy can inhibit (Baker et al. 2017; Baker et al. 2018; Sabatino et al. 2018), but in some instances augment MS, possibly due to influences on distinct B cell subsets (Kappos et al. 2014; Baker et al. 2017). Therefore, actual use will demonstrate where the therapeutic balance resides, but targeting memory B cell responses inhibits MS (Baker et al. 2017a). There are a number of agents that could be used to target $B$ cells. 
Cyclophosphamide is prodrug that is metabolised to a cytostatic agent that kills rapidly dividing cells and thus can target some B cells by virtue of their activation or by because B cells exhibit a higher turnover rate compared to other cells such as T cells (Macallan et al. 2003; Macallan et al. 2005). Therefore B cells may be more sensitive to cytostatic agents, although low-dose pulsed cyclophosphamide exhibits limited effects on plasma cells and memory B cells (Fassbinder et al. 2015). However, high-dose $(120 \mathrm{mg} / \mathrm{kg}-200 \mathrm{mg} / \mathrm{kg})$ cyclophosphamide has been used extensively in people with progressive MS, as part of a monotherapy or as part of Haematopoeitic Stem Cell Therapy (HSCT) to induce mobilisation of CD34+ stem cells (La Mantia et al. 2007; Krishan et al. 2008; Bowen et al 2012; Atkins et al. 2016; Brochet al. 2017). Whilst cyclophosphamide and HSCT have exhibited marked impact on relapsing and active MS (Krishan et al. 2008; Aktins et al. 2016), people with progression have often continued to progress, although some people with advanced (progressive) MS appear to show some benefit (Bowen et al. 2012). However, people with MS often poorly tolerate cyclophosphamide, consistent with the non-selective activity on dividing cells including hair loss and gastrointestinal problems (La mantia et al. 2007; Krishan et al. 2008). Many people continue to show some worsening and OCB have persisted $(60-160 \mathrm{mg} / \mathrm{kg})$ indicating ineffective CNS clearance of B cells within their CNS niches (Openshaw et al. 2000; Saiz et al. 2001; Carreras et al. 2003; Nash et al. 2012; Bowen et al. 2012).

Mitoxantrone is a type II topoisomerase inhibitor that disrupts DNA synthesis and repair and intercalates into DNA bases and kills dividing cells and so may target dividing B cells that are turning over (Macallan et al. 2005). Mitoxantrone depletes B cells and notably exhibits a marked impact on memory B cell in MS, consistent with its efficacy (Chan et al. 2005; Duddy et al. 2007; Baker et al. 2017). Pixantrone, a mitoxantrone analogue, is also a potent depleter of $B$ cells (Gonsette et al. 2018). When mitoxantrone was used in combination with CD20-depletion there was marked depletion of peripheral blood $B$ cells and also reductions, albeit to a more modest and transient level. of $B$ cells with the cerebrospinal fluid that was associated with a positive treatment effect (Evdoshenko et al. 2013). Mitoxantrone is used for the treatment of active advanced MS (Martinelli Boneschi et al. 2013). It can show a significant but partial efficacy in reducing the risk of MS progression and the frequency of relapses in some but not all studies (Martinelli Boneschi et al. 2013; Grey Née Cotte et al. 2015). However, mitoxantrone is neurotoxic and is actively excluded from the CNS via the action of ABCG2 ATP-binding cassette transporter (Dalle et al. 2000; Cotte et al. 2009). The influence on OCB is also limited (Axelsson et al. 2013). This coupled with concerns about the risk of cardiotoxicity and therapy-related acute leukaemias, limit the value of mitoxantrone (Martinelli Boneschi et al. 2013).

Cladribine produces toxic moieties following phosphorylation of the adeonosine-analogue by deoxycytidine kinase and selectively kills, dividing and non-dividing, lymphocytes notably B lymphocytes (Giovannoni et al. 2017; Ceronie et al. 2018). Oral cladribine prodrug inhibits relapsing MS (Giovannoni et al. 2017). Likewise, parenteral, generic cladribine inhibits disease 
activity in relapsing and progressive disease (Giovannoni et al. 2017, Rice et al. 2000). Although there is a perceived failure in progressive MS (Beutler et al. 1996; Rice et al. 2000), the trials were too short to really demonstrate full clinical benefit and there were positive imaging and clinical effects (Rice et al. 2000) and unlike any other licenced disease modifying treatment in MS, the drug is CNS penetrant (Figure 1) and can be active in the CNS (Kearns et al. 1994; Baker et al. 2019). Cladribine probably behaves as chemical anti-CD19 agent, with additional T cell inhibitory activity, based on the high expression of deoxcytidine kinase (DCK) in B cells, which facilitates cladribine-induced apoptosis of lymphocytes (Cocco et al. 2012; Baker et al. 2019). It is evident that DCK is expressed on early $B$ cell lineages including immature, mature, memory B cells and plasmablasts but is down regulated in plasma cells (Cocco et al. 2012; Ceronie et al. 2018; Baker et al. 2019). However, parenteral cladribine has reduced or eliminated the occurrence of OCB in some people with MS (Sipe et al. 1994, Rejdak et al. 2018), suggesting that it can inhibit the development of plasma cells or that it blocks the factors that promote $\mathrm{B}$ cell niches within the CNS. Cladribine like alemtuzumab and ocrelizumab has some immunereconstitution therapy potential, with a long-term benefit from a short course of treatment (Giovannoni et al. 2018). As such this may also provide an immunomodulatory platform on which to layer neuroprotection and repair.

Mycophenolate is a lymphocyte-selective depleting agent that is metabolised in the plasma and the liver into mycophenolic acid, which is a reversible inhibitor of inosine monophosphate dehydrogenase (IMPDH) involved in de novo purine biosynthesis. This pathway is essential for lymphocyte proliferation (Euqui et al. 1991). However, there is limited data concerning benefit of use in MS, but it may inhibit active disease (Michel et al. 2014; Xioa et al. 2014; Fakih et al. 2018). This agent can inhibit $B$ cell activation and differentiation in vitro, although terminally differentiated plasma cells appear to less sensitive to the effects of mycophenolate, possibly due to down regulation and insensitivity of the IMPDH (Karnell et al. 2011). However there does not appear to be gross changes in most B cell subsets following treatment with mycophenolic acid in humans, although in some instance plasma cells appeared to be reduced in non-MS conditions (Zhao et al. 2012; San Sequndo et al. 2012; Fickenberg et al. 2012). However the influence on $B$ cell subsets require study and positive effects on non-active elements of progressive MS have yet to be found (Fakih et al. 2018).

\section{B CELL-SELECTIVE INHIBITORS}

Given the success of B cell depletion using CD20 monoclonal antibodies, there is significant commercial interest in developing B cell depleting agents or B cell inhibitors.

Brutons tyrosine kinase (BTK) inhibitors reversibly or irreversibly block the BTK enzyme that plays a crucial signalling role in B cell development and mutations in BTK are associated with X-linked agammaglobulinemia, where B cell fails to mature. BTK inhibitors prevent B cell activation and block downstream B cell survival pathways. There are a number of BTK inhibitors in clinical development, initially for cancer and the first study in MS has been reported to have 
a positive impact in active disease using evobrutinib (Montalban et al. 2019). This is a first generation BTKi that has been reported to the inhibit lesion formation and the generation of relapses in phase II trials (Montalban et al. 2018). This also inhibits macrophage function and may thus have additional activities relevant for advanced MS (Alankus et al. 2018). Some first generation agents have been approved for treating haematological malignancies and graft versus host disease, such as Ibrutinib. This is appears to be a p-glycoprotein substrate, which may limit CNS penetration (van Hoppe et al. 2018) and infections following use commonly occur (Tillman et al. 2018; Hsiehchen et al. 2018). Second generation inhibitors are been developed that have fewer side effects and greater specificity (Wu et al. 2016; Pal Singh et al. 2018). There is significant commercial interest in BTKi development and include agents such as PRM226, which is a CNS penetrant BTKi, ABBV-105 and HM71224/LY3337641 (Wu et al. 2016; Robak \& Robak 2017; Pal Singh et al. 2018). However, although caution is needed when comparing studies, the reduction in the of level formation by evobrutinib does not appear to as marked as found with CD20-depletion and this may have implications for staging within the therapeutic ladder of MS treatments (Kappos et al. 2011; Montalban et al. 2019). In addition, BTKi have been used to augment cancer therapy when used in combination with other agents (Geyer et al. 2019). It remains to be seen whether there could be benefit from being used as add-on therapy in MS. This will become clearer as more studies are undertaken and published.

Proteosome Inhibitors. The proteasome plays a pivotal role in the control of many cell cycleregulatory processes, including regulation of nuclear factor Kappa B activity and control of apoptosis (Schenken 2002). Proteasome inhibitors can sensitize cells to induce apoptosis and have been used to treated multiple myeloma, using agents such as bortezomib that is partially excluded from the CNS by p-glycoprotein (Forn at al. 2016). One could use such an agent to make advantage of the finding that $\mathrm{p}$-glycoprotein exclusion pump is down-regulated in MS lesions, to selectively target areas of pathology (Al-Izki et al. 2014). However, bortezomib can have undesirable side-effects such as the induction of neuropathy (Alé et al. 2014). There are second generation inhibitors such as carfilzomib and ixazomib, with more limited neuropathic effects (Karademir et al. 2018). These inhibitors target plasma cells, but also have impact on activated naïve and memory $B$ cells and may have activity against peripheral autoimmunity (Mulder et al. 2013, Alexander et al. 2015). CNS-penetrant proteosome inhibitors such as marizomib have been generated ( $\mathrm{Di}$ et al. 2016). It remains to be seen whether these agents will have merit in the treatment of MS and whether they can be used long-term to treat MS, especially as proteasome activators may be neuroprotective (Schattling et al. 2019).

\section{B CELL SURVIVAL FACTORS}

There are a number of B cell growth, differentiation and survival factors including interleukin 4, Interleukin 6, Interleukin 10 and Interleukin 13, lymphotoxin and tumour necrosis factor, and a number of chemokines notably B cell-attracting chemokine 1/CXCL13, which support B cell growth and survival (Housley et al. 2016). Many can be inhibited by specific monoclonal antibodies such as tocilizumab (IL-6 receptor) and siltuximab (IL-6) and others (Klimatcheva et 
al. 2015; Beauchemin \& Carruthers 2016). However, these will have the same CNS penetration issues as agents targeting $B$ cell surface markers and some may have unwanted activities (Beauchemin \& Carruthers 2016; Kemanetzoglou \& Andreadou 2017). Inhibition of B cell activating factor (BAFF. TNFLS13B) and a proliferation proliferation-inducing ligand (APRIL) serves as a warning that not all B cell inhibitors are beneficial (Reviewed in Baker et al. 2017). Atacicept is a fusion protein of the transmembrane activator and calcium modulator and cyclophilin-ligand interactor (TACI. TNFRSF13B) receptor that blocks BAFF and APRIL to deplete mature B cells and plasma cells, but not memory cells and appears to augment MS relapse (Kappos et al. 2014; Sergott et al. 2015; Reviewed in Baker et al. 2017). It is therefore of interest that studies with monoclonal inhibition of BAFF using tabalumab did not inhibit lesion formation, but importantly it did appear to worsen MS (Silk \& Nantz 2018). BAFF stimulates the TACI receptor, the BAFF-receptor (TNFRSF13C) expressed by most B lineage cells and the $B$ cell maturation antigen receptor (TNFRSF17), which highly expressed by mainly be plasma cells (Mackay et al. 2003; Darce et al. 2007). APRIL stimulates TACI, expressed by memory B cells and plasma cells (www.biogps,org) and BCMA (Mackay et al. 2003; Darce et al. 2007), but interestingly inhibition of BAFF with belimumab does not appear to augment the memory B cell response (Ramsköld et al. 2018). Therefore, this not only implicates APRIL as a problematic growth factor in MS, importantly if provides yet more evidence to support the hypothesis that the memory B cells are central mediators in the pathogenesis of MS (Reviewed in Baker et al. 2017).

\section{TUMOUR NECROSIS FACTOR INHIBITORS.}

Tumour necrosis factor (TNF) is a plasma cell survival factor and a number of the markers involved in B cell development are members of the TNF superfamily such as CD40 and CD27, which are MS susceptibility genes (Jourdan et al. 1999, Dendrou et al. 2013; Fliggett et al. 2014). Inhibitors of TNF are used to treat multiple myeloma indicating the sensitivity of B cells to these treatments. Most MS treatments are also active in other autoimmune diseases, but inhibition of TNF has been a notable exception and even appears to augment CNS demyelinating disease (Kemanetzoglou \& Andreadou 2017). Whilst it has been postulated that TNF inhibition can augment memory B cell responses and so drive relapsing MS (Baker et al 2017a), other explanations are possible (Kemanetzoglou \& Andreadou 2017). As such, because antibodies are largely excluded from the CNS, there is a possibly that there is no inhibition of TNF within the CNS and therefore no inhibition of local B cell responses occurs in MS, unlike in other TNF inhibition-sensitive peripheral autoimmunities. As such it has been shown that TNF contributes to the formation of ectopic $B$ cell follicles and these may contribute to disease progression in MS (Paulino et al. 2018, Pryce \& Baker 2018; Baker et al. 2018). Peripheral inhibition of TNF has been shown to block B cell follicles (Cañete et al. 2009; Pryce \& Baker 2018). This would suggest benefit may be driven by targeting CNS-derived TNF (Figure 1. Baker et al. 1994). 
Intrathecal/Ventricular TNF inhibition. There is experimental evidence the local delivery of TNF into the CNS offers benefit over systemic delivery (Baker et al. 1994). However, given the history of anti-TNF treatment in MS, this approach will be difficult to recruit and undertake.

Phophosphodiesterase 4 (PDE4) Inhibition. There is evidence that PDE4 inhibitors are potent TNF inhibitors and consistent with this, rolipram may even augment relapsing MS disease (Sommer et al. 1995, Bielekova et al. 2009). However, worsening was not found with Ibudilast which also did not inhibit relapsing MS (Barkhof et al. 2010). Ibudilast is a CNS-penetrant phosphodiesterase 4 and migration inhibition factor inhibitor that may have some benefit in progressive MS, in contrast to pentoxyfylline, and has slowed brain volume loss in MS (Meyers et al. 1998; Fox et al. 2018). Whether this targets intrathecal B cell responses is currently unknown.

Thalidomide Analogues. Thalidomide is also used to treat myeloma and is a potent inhibitor of TNF, however it produces tetragenic effects. There are a number of thalidomide analogues that have fewer side effects such as: lenalidomide, pomaldomide and apremilolast. Pomalidomide is used to treat multiple myeloma (Gueneau et al. 2018). It remains to be seen whether they could target plasma cell responses in the CNS during MS.

\section{VACCINATION THERAPY}

Chimeric Antigen Receptor T cells (CAR-T) Therapy. A novel immunotherapy has emerged for cancer immunotherapy, whereby (CD8) T cells from individuals can be engineered to express cell-specific single chain variable antibody fragments that give specificity and signal $\mathrm{T}$ cell activation following ligation (Ruella \& June 2016). Initial targeting constructs have been designed to target all CD19 or CD20 B cells (Ruella \& June 2016; Zhang et al. 2017; Perales et al. 2018). These CART cells would have the capacity to enter the CNS to kill B cells, including the memory $B$ cells and plasmablasts, which are the dominant B cell subsets with the CNS (Eggers et al. 2017). Tisagenlecleucel, which targets CD19 B cells has been licenced after success in cancer (Zhang et al. 2016). However, this therapy is not currently reversible and will lead to permanent depletion of all CD19 B cells, as they form and they will not directly target long-lived plasma cells that do not express CD19. These CAR-T cells will probably lead to the infection problems that have been associated with long-term $B$ cell deletion using antibodies. The creation of more selective CAR-T and development of the technology for reversible, safer use of CART therapy would probably be ideally needed for use in MS (Duong et al. 2017; Perales et al. 2018). Recently, B cell maturation antigen (CD269) CAR-T cells have been produced for multiple myeloma, which will target $B$ memory cells and notably plasma cells and may offer real promise for targeting pathogenic B cells with the CNS in the future (Cohen et al. 2019).

Epstein Barr Virus vaccination to kill virally-infected B cells. Epstein Barr virus, which may be the aetiological trigger of MS, infects $B$ cells and causes expansion of memory $B$ cells (Burns et al. 2015, Burns et al. 2016, Reviewed in Baker et al. 2018). These may presentation antigen 
to $T$ cells to drive MS (Reviewed in Baker et al. 2017). This virus creates survival advantage for the $B$ cell and therefore killing of the virus may limit B cell activity. This may be achieved using EBV-specific CD8 cytotoxic cells (Pender \& Burrows 2014). This approach is being trialled and commercially developed for MS and may offer some benefit in progressive MS (Pender MP et al. 2017).

\section{SUMMARY}

As $B$ cells are increasing been seen as an important pathogenic element of relapsing and progressive MS (Baker et al. 2017; Baker et al. 2018) searches for novel agents will increase. However, whilst these may offer promise, the failure and potential worsening of some B cell inhibitory agents (Sergott et al. 2015), indicates that until appropriate trials are under taken their potential efficacy and safety cannot necessarily be predicted (Kappos et al. 2014, Sergott et al. 2015).

Funding Information. This received study received no funding.

Disclosures of Interest: None considered relevant but DB is a shareholder of Canbex Therapeutics. Honoraria for consultant activities have been received from Canbex therapeutics, Japan tobacco, Merck Serono, Roche and Sanofi-Genzyme. BMJ has nothing to declare. SG has received honoraria and meeting support from Biogen, Novartis, Teva, Genzyme and research funds from Genzyme and Takeda. KS has been a principal investigator of trials sponsored by Novartis, Roche and Teva and involved in trials sponsored by Biogen, Sanofi-Genzyme, BIAL, Cytokinetics, and Canbex and has received honoraria and meeting support from Biogen, Novartis, and Teva. GG has received fees for participation in advisory board from AbbVie Biotherapeutics, Biogen, Canbex, Ironwood, Japan tobacco, Novartis, Merck, Roche, Sanofi Genzyme, Synthon, Teva and Vertex; speaker fees from AbbVie, Biogen, Bayer HealthCare, Genzyme, Sanofi-Aventis and Teva. Research support from Biogen, Genzyme, Ironwood, Merck, Merck Serono, Novartis and Takeda. GG is an editor of Multiple sclerosis and Related Disorders 


\section{REFERENCES}

Al-Salama ZT. Siponimod: First Global Approval. Drugs. 2019. doi: 10.1007/s40265-019-01140x. [Epub].

Alé A, Bruna J, Navarro X, Udina E. Neurotoxicity induced by antineoplastic proteasome inhibitors. Neurotoxicology. 2014;43:28-35.

Alexander T, Sarfert R, Klotsche J, Kühl AA, Rubbert-Roth A, Lorenz HM, Rech J, Hoyer BF, Cheng Q, Waka A, Taddeo A, Wiesener M, Schett G, Burmester GR, Radbruch A, Hiepe F, Voll RE. The proteasome inhibitior bortezomib depletes plasma cells and ameliorates clinical manifestations of refractory systemic lupus erythematosus. Ann Rheum Dis. 2015; 74:1474-1478.

Al-Izki S, Pryce G, Hankey DJ, Lidster K, von Kutzleben SM, Browne L, Clutterbuck L, Posada C, Edith Chan AW, Amor S, Perkins V, Gerritsen WH, Ummenthum K, Peferoen-Baert R, van der Valk P, Montoya A, Joel SP, Garthwaite J, Giovannoni G, Selwood DL, Baker D. Lesional-targeting of neuroprotection to the inflammatory penumbra in experimental multiple sclerosis. Brain. $2014 ; 137: 92-108$.

Alankus Y, Grenningloh R, Haselmayer P, Bender A, Bruttger J. BTK inhibition prevents inflammatory macrophage differentiation: a potential role in MS. Mult scler J 2018; 24 (S2):264

Atkins HL, Bowman M, Allan D, Anstee G, Arnold DL, Bar-Or A, Bence-Bruckler I, Birch P, Bredeson C, Chen J, Fergusson D, Halpenny M, Hamelin L, Huebsch L, Hutton B, Laneuville P, Lapierre $Y$, Lee H, Martin L, McDiarmid S, O'Connor P, Ramsay T, Sabloff M, Walker L, Freedman MS. Immunoablation and autologous haemopoietic stem-cell transplantation for aggressive multiple sclerosis: a multicentre single-group phase 2 trial. Lancet. 2016; 388:576-85

Axelsson M, Mattsson N, Malmeström C, Zetterberg H, Lycke J. The influence of disease duration, clinical course, and immunosuppressive therapy on the synthesis of intrathecal oligoclonal IgG bands in multiple sclerosis. J Neuroimmunol. 2013; 264:100-5

Baker D, Butler D, Scallon BJ, O'Neill JK, Turk JL, Feldmann M. Control of established experimental allergic encephalomyelitis by inhibition of tumor necrosis factor (TNF) activity within the central nervous system using monoclonal antibodies and TNF receptorimmunoglobulin fusion proteins. Eur J Immunol. 1994; 24:2040-2048.

Baker D, Marta M, Pryce G, Giovannoni G, Schmierer K. Memory B Cells are major targets for effective immunotherapy in relapsing multiple sclerosis. EBioMedicine. 2017; 16:41-50. 
Baker D, Pryce G, Amor S, Giovannoni G, Schmierer K. Learning from other autoimmunities to understand targeting of B cells to control multiple sclerosis. Brain. 2018; 141:2834-2847.

Baker D, Pryce G, Herrod SS, Schmierer K. Potential mechanisms of action related to the efficacy and safety of cladribine. Mult Scler Relat Disord. 2019; 30:176-186.

Barkhof F, Hulst HE, Drulovic J, Uitdehaag BM, Matsuda K, Landin R; MN166-001 Investigators.Ibudilast in relapsing-remitting multiple sclerosis: a neuroprotectant? Neurology. 2010; 74:1033-1040.

Bar-Or A, Grove RA, Austin DJ, Tolson JM, VanMeter SA, Lewis EW, Derosier FJ, Lopez MC, Kavanagh ST, Miller AE, Sorensen PS. Subcutaneous ofatumumab in patients with relapsingremitting multiple sclerosis: The MIRROR study.Neurology. 2018; 90:e1805-e1814.

Bergman J, Burman J, Gilthorpe JD, Zetterberg H, Jiltsova E, Bergenheim T, Svenningsson A. Intrathecal treatment trial of rituximab in progressive MS: An open-label phase $1 \mathrm{~b}$ study. Neurology. 2018; 91:e1893-e1901.

Bielekova B, Richert N, Howard T, Packer AN, Blevins G, Ohayon J, McFarland HF, Stürzebecher CS, Martin R. Treatment with the phosphodiesterase type-4 inhibitor rolipram fails to inhibit blood--brain barrier disruption in multiple sclerosis. Mult Scler. 2009; 15:1206-1214

Bowen JD, Kraft GH, Wundes A, Guan Q, Maravilla KR, Gooley TA, McSweeney PA, Pavletic SZ, Openshaw H, Storb R, Wener M, McLaughlin BA, Henstorf GR, Nash RA. Autologous hematopoietic cell transplantation following high-dose immunosuppressive therapy for advanced multiple sclerosis: long-term results. Bone Marrow Transplant. 2012; 47:946-51.

Brochet B, Deloire MS, Perez P, Loock T, Baschet L, Debouverie M, Pittion S, Ouallet JC, Clavelou $P$, de Sèze $J$, Collongues $N$, Vermersch $P$, Zéphir $H$, Castelnovo $G$, Labauge $P$, Lebrun $C$, Cohen $M$, Ruet A; PROMESS study investigators. Double-blind controlled randomized trial of cyclophosphamide versus methylprednisolone in secondary progressive multiple sclerosis. PLoS One. $2017 ; 12: \mathrm{e} 0168834$

Beauchemin P, Carruthers R. MS arising during Tocilizumab therapy for rheumatoid arthritis. Mult Scler. 2016; 22:254-256.

Beutler E, Sipe JC, Romine JS, Koziol JA, McMillan R, Zyroff J. The treatment of chronic progressive multiple sclerosis with cladribine. Proc Natl Acad Sci U S A. 1996; 93:1716-1720.

Burns DM, Rana S, Martin E, Nagra S, Ward J, Osman H, Bell AI, Moss P, Russell NH, Craddock $\mathrm{CF}$, Fox $\mathrm{CP}$, Chaganti S.Greatly reduced risk of EBV reactivation in rituximab-experienced 
recipients of alemtuzumab-conditioned allogeneic HSCT. Bone Marrow Transplant. 2016; 51:825-32.

Burns DM, Tierney R, Shannon-Lowe C, Croudace J, Inman C, Abbotts B, Nagra S, Fox CP, Chaganti S, Craddock CF, Moss P, Rickinson AB, Rowe M, Bell AI.Memory B-cell reconstitution following allogeneic hematopoietic stem cell transplantation is an EBV-associated transformation event. Blood. 2015; 126:2665-2675.

Burris HA, Infante JR, Ansell SM, Nemunaitis JJ, Weiss GR, Villalobos VM, Sikic BI, Taylor MH, Northfelt DW, Carson WE 3rd, Hawthorne TR, Davis TA, Yellin MJ, Keler T, Bullock T. Safety and activity of varlilumab, a novel and first-in-class agonist anti-cd27 antibody, in patients with advanced solid tumors. J Clin Oncol. 2017; 35:2028-2036.

Cañete JD, Celis R, Moll C, Izquierdo E, Marsal S, Sanmartí R, Palacín A, Lora D, de la Cruz J, Pablos JL. Clinical significance of synovial lymphoid neogenesis and its reversal after anti-tumour necrosis factor a therapy in rheumatoid arthritis. Ann Rheum Dis. 2009; 68:751-756.

Carreras E, Saiz A, Marín P, Martínez C, Rovira M, Villamor N, Aymerich M, Lozano M, FernándezAvilés F, Urbano-Izpizua A, Montserrat E, Graus F. CD34+ selected autologous peripheral blood stem cell transplantation for multiple sclerosis: report of toxicity and treatment results at one year of follow-up in 15 patients. Haematologica. 2003; 88:306-314.

Castillo-Trivino T, Braithwaite D, Bacchetti P, Waubant E. Rituximab in relapsing and progressive forms of multiple sclerosis: a systematic review. PLoS One. 2013; 8:e66308.

Ceronie B, Jacobs BM, Baker D, Dubuisson N, Mao Z, Ammoscato F, Lock H, Longhurst HJ, Giovannoni G, Schmierer K. Cladribine treatment of multiple sclerosis is associated with depletion of memory B cells. J Neurol. 2018; 265:1199-1209.

Chan A, Weilbach FX, Toyka KV, Gold R. Mitoxantrone induces cell death in peripheral blood leucocytes of multiple sclerosis patients. Clin Exp Immunol. 2005; 139:152-158

Cocco M, Stephenson S, Care MA, Newton D, Barnes NA, Davison A, Rawstron A, Westhead DR, Doody GM, Tooze RM. In vitro generation of long-lived human plasma cells. J Immunol. 2012; 189:5773-5785.

Cohen AD, Garfall AL, Stadtmauer EA, Melenhorst JJ, Lacey SF, Lancaster E, Vogl DT, Weiss BM, Dengel K, Nelson A, Plesa G, Chen F, Davis MM, Hwang WT, Young RM, Brogdon JL, Isaacs R, Pruteanu-Malinici I, Siegel DL, Levine BL, June $\mathrm{CH}$, Milone MC. B cell maturation antigen-specific CAR T cells are clinically active in multiple myeloma. J Clin Invest. 2019 21; 130. pii: 126397 
Cotte S, von Ahsen N, Kruse N, Huber B, Winkelmann A, Zettl UK, Starck M, König N, Tellez N, Dörr J, Paul F, Zipp F, Lühder F, Koepsell H, Pannek H, Montalban X, Gold R, Chan A. ABCtransporter gene-polymorphisms are potential pharmacogenetic markers for mitoxantroneresponse in multiple sclerosis. Brain. 2009; 132:2517-2530.

Dalle JH, Lambilliotte A, Defachelles AS, Mazingue F, Nelken B. Intrathecal mitozantrone has to be prohibited. Leukemia. 2000; 14:2323-2324.

Darce JR, Arendt BK, Wu X, Jelinek DF. Regulated expression of BAFF-binding receptors during human B cell development J. Immmunol 2007: 179:7276-7286.

Dendrou CA, Bell JI, Fugger L.A clinical conundrum: the detrimental effect of TNF antagonists in multiple sclerosis. Pharmacogenomics. 2013; 14:1397-1404.

Di K, Lloyd GK, Abraham V, MacLaren A, Burrows FJ, Desjardins A, Trikha M, Bota DA. Marizomib activity as a single agent in malignant gliomas: ability to cross the blood-brain barrier.Neurol $2016 ; 18: 840-848$

Dooley J, Pauwels I, Franckaert D, Smets I, Garcia-Perez JE, Hilven K, Danso-Abeam D, Terbeek J, Nguyen AT, De Muynck L, Decallonne B, Dubois B, Liston A, Goris A. Immunologic profiles of multiple sclerosis treatments reveal shared early $B$ cell alterations. Neurol Neuroimmunol Neuroinflamm. 2016; 3:e240.

Du FH, Mills EA, Mao-Draayer Y. Next-generation anti-CD20 monoclonal antibodies in autoimmune disease treatment. Auto Immun Highlights. 2017; 8:12

Duddy M., Niino M., Adatia F. Distinct effector cytokine profiles of memory and naive human B cell subsets and implication in multiple sclerosis. J. Immunol. 2007; 178:6092-6099.

Duong MT, Collinson-Pautz MR, Morschl E, Lu A, Szymanski SP, Zhang M, Brandt ME, Chang WC, Sharp KL, Toler SM, Slawin KM, Foster AE, Spencer DM, Bayle JH.Two-dimensional regulation of CAR-T Cell therapy with orthogonal switches. Mol Ther Oncolytics. 2018; 12:124-137

Eggers EL, Michel BA, Wu H, Wang SZ, Bevan CJ, Abounasr A, Pierson NS, Bischof A, Kazer M, Leitner E, Greenfield AL, Demuth S, Wilson MR, Henry RG, Cree BA, Hauser SL, von Büdingen $\mathrm{HC}$ Clonal relationships of CSF B cells in treatment-naive multiple sclerosis patients. JCI Insight. 2017; 2. pii: 92724. 
Emery P, Rigby W, Tak PP, Dörner T, Olech E, Martin C, Millar L, Travers H, Fisheleva E. Safety with ocrelizumab in rheumatoid arthritis: results from the ocrelizumab phase III program._PLoS One. 2014; 9: e87379.

Evdoshenko E, Maslyanskiy A, Lapin S, Zaslavsky L, Dobson R, Totolian A, Skoromets A, Bar-Or A. Dynamics of B-Cell Populations in CSF and Blood in Patients Treated with a Combination of Rituximab and Mitoxantrone. ISRN Neurol. 2013; 2013:748127.

Eugui EM, Almquist SJ, Muller CD, Allison AC. Lymphocyte-selective cytostatic and immunosuppressive effects of mycophenolic acid in vitro: role of deoxyguanosine nucleotide depletion. Scand J Immunol. 1991; 33:161-173.

Fakih R, Matiello M, Chitnis T, Stankiewicz JM.Efficacy and safety of mycophenolate mofetil in progressive multiple sclerosis patients.J Neurol. 2018; 265:2688-2694

Fassbinder T, Saunders U, Mickholz E, Jung E, Becker H, Schlüter B, Jacobi AM. Differential effects of cyclophosphamide and mycophenolate mofetil on cellular and serological parameters in patients with systemic lupus erythematosus. Arthritis Res Ther. 2015; 17:92.

Eickenberg S, Mickholz E, Jung E, Nofer JR, Pavenstadt HJ, Jacob AM. Mycophenolic acid counteracts $B$ cell proliferation and plasmablast formation in patients with systemic lupus erythematosus. Arth Res Ther 2012; 14:R110.

Figgett WA, Vincent FB, Saulep-Easton D, Mackay F. Roles of ligands from the TNF superfamily in B cell development, function, and regulation. Semin Immunol. 2014; 26:191-202

Foran E, Kwon DY,Nofziger JH, Arnold ES, Hall MD,Fischbeck KH, Burnett BG CNS uptake of bortezomib is enhanced by $\mathrm{P}$-glycoprotein inhibition: implications for spinal muscular atrophy. Neurobiol Dis. 2016; 88: 118-124.

Fox RJ, Coffey CS, Conwit R, Cudkowicz ME, Gleason T, Goodman A, Klawiter EC, Matsuda K, McGovern M, Naismith RT, Ashokkumar A, Barnes J, Ecklund D, Klingner E, Koepp M, Long JD, Natarajan S, Thornell B, Yankey J, Bermel RA, Debbins JP, Huang X, Jagodnik P, Lowe MJ, Nakamura K, Narayanan S, Sakaie KE, Thoomukuntla B, Zhou X, Krieger S, Alvarez E, Apperson M, Bashir K, Cohen BA, Coyle PK, Delgado S, Dewitt LD, Flores A, Giesser BS, Goldman MD, Jubelt B, Lava N, Lynch SG, Moses H, Ontaneda D, Perumal JS, Racke M, Repovic P, Riley CS, Severson C, Shinnar S, Suski V, Weinstock-Guttman B, Yadav V, Zabeti A; NN102/SPRINT-MS Trial Investigators. Phase 2 Trial of Ibudilast in Progressive Multiple Sclerosis. N Engl J Med. $2018 ; 379: 846-855$ 
Gandoglia I, Ivaldi F, Laroni A, Benvenuto F, Solaro C, Mancardi G, Kerlero de Rosbo N, Uccelli A. Teriflunomide treatment reduces $B$ cells in patients with MS. Neurol Neuroimmunol Neuroinflamm. 2017; 4:e403

Geyer MB, Rivière I, Sénéchal B, Wang X, Wang Y, Purdon TJ, Hsu M, Devlin SM, Palomba ML, Halton E, Bernal Y, Sadelain M, Park JH, Brentjens RJ. Safety and tolerability of conditioning chemotherapy followed by CD19-targeted CAR T cells for relapsed/refractory CLL. JCI Insight. 2019; 5. pii: 122627.

Giovannoni G. Cladribine to Treat Relapsing Forms of Multiple Sclerosis. Neurotherapeutics. 2017; 14:874-887.

Giovannoni G. Disease-modifying treatments for early and advanced multiple sclerosis: a new treatment paradigm. Curr Opin Neurol. 2018; 31:233-243.

Giovannoni G, Soelberg Sorensen P, Cook S, Rammohan K, Rieckmann P, Comi G, Dangond F, Adeniji AK, Vermersch P. Safety and efficacy of cladribine tablets in patients with relapsingremitting multiple sclerosis: Results from the randomized extension trial of the CLARITY study. Mult Scler. 2018; 24:1594-1604.

Gonsette R, Debouverie M, Sindic C, Ferré JC, Edan G. Pixantrone: a B-cell-depleting immunosuppressant for multiple sclerosis patients with active disease. Mult Scler. 2016; 22:817821.

Grey Née Cotte S, Salmen Née Stroet A, von Ahsen N, Starck M, Winkelmann A, Zettl UK, Comabella M, Montalban X, Zipp F, Fleischer V, Kruse N, Gold R, Chan A. Lack of efficacy of mitoxantrone in primary progressive Multiple Sclerosis irrespective of pharmacogenetic factors: a multi-center, retrospective analysis. J Neuroimmunol. 2015; 278:277-9.

Gueneau P, Chretien ML, Cransac-Miet A, Aho LS, Lafon I, Favennec C, Guy J, Caillot D, Boulin M. Efficacy, safety, and cost of pomalidomide in relapsed and refractory multiple myeloma. Eur J Haematol. 2018 doi: 10.1111/ejh.13039. [Epub ahead of print]

Harigai M, Tanaka Y, Maisawa S; JA21963 Study Group. Safety and efficacy of various dosages of ocrelizumab in Japanese patients with rheumatoid arthritis with an inadequate response to methotrexate therapy: a placebo-controlled double-blind parallel-group study. J Rheumatol. 2012; 39:486-95.

Hauser SL, Bar-Or A, Comi G, Giovannoni G, Hartung HP, Hemmer B, Lublin F, Montalban X, Rammohan KW, Selmaj K, Traboulsee A, Wolinsky JS, Arnold DL, Klingelschmitt G, Masterman D, Fontoura P, Belachew S, Chin P, Mairon N, Garren H, Kappos L; OPERA I and OPERA II Clinical 
Investigators. Ocrelizumab versus Interferon Beta-1a in Relapsing Multiple Sclerosis. N Engl J Med. 2017; 376:221-234

Hawker K, O'Connor P, Freedman MS, Calabresi PA, Antel J, Simon J, Hauser S, Waubant E, Vollmer T, Panitch $\mathrm{H}$, Zhang J, Chin $\mathrm{P}$, Smith $\mathrm{CH}$; OLYMPUS trial group. Rituximab in patients with primary progressive multiple sclerosis: results of a randomized double-blind placebocontrolled multicenter trial. Ann Neurol. 2009; 66:460-471.

Housley WJ, Pitt D, Hafler DA. Biomarkers in multiple sclerosis. Clin Immunol. 2015;161:51-58.

Ireland SJ, Blazek M, Harp CT, Greenberg B, Frohman EM, Davis LS, Monson NL. Antibodyindependent $B$ cell effector functions in relapsing remitting multiple sclerosis: clues to increased inflammatory and reduced regulatory B cell capacity. Autoimmunity. 2012; 45:400-414.

Hsiehchen D, Arasaratnam R, Raj K, Froehlich T, Anderson L. Ibrutinib Use Complicated by Progressive Multifocal Leukoencephalopathy. Oncology. 2018; 95:319-322.

Jourdan M,Tarte K, Legouffe E, Brochier J, Rossi J-F, Klein B. Tumor necrosis factor is a survival and proliferation factor for human myeloma cells Eur Cytokine Netw. 1999; 10: 65-70.

Karademir B, Sari G, Jannuzzi AT, Musunuri S, Wicher G, Grune T, Mi J, Hacioglu-Bay H, Forsberg-Nilsson K, Bergquist J, Jung T. Proteomic approach for understanding milder neurotoxicity of Carfilzomib against Bortezomib. Sci Rep. 2018; 8:16318.

Kappos L, Li D, Calabresi PA, O'Connor P, Bar-Or A, Barkhof F, Yin M, Leppert D, Glanzman R, Tinbergen J, Hauser SL. Ocrelizumab in relapsing-remitting multiple sclerosis: a phase 2, randomised, placebo-controlled, multicentre trial. Lancet. 2011; 378:1779-1787.

Kappos L, Hartung HP, Freedman MS, Boyko A, Radü EW, Mikol DD, Lamarine M, Hyvert Y, Freudensprung $U$, Plitz T, van Beek J; ATAMS Study Group. Atacicept in multiple sclerosis (ATAMS): a randomised, placebo-controlled, double-blind, phase 2 trial. Lancet Neurol. 2014; 13:353-63.

Karnell JL, Karnell FG 3rd, Stephens GL, Rajan B, Morehouse C, Li Y, Swerdlow B, Wilson M, Goldbach-Mansky R, Groves C, Coyle AJ, Herbst R, Ettinger R. Mycophenolic acid differentially impacts B cell function depending on the stage of differentiation. J Immunol. 2011; 187:36033612

Kearns CM, Blakley RL, Santana VM, Crom WR. Pharmacokinetics of cladribine (2chlorodeoxyadenosine) in children with acute leukemia. Cancer Res. 1994; 54:1235-1239. 
Kemanetzoglou E, Andreadou E. CNS Demyelination with TNF-a Blockers. Curr Neurol Neurosci Rep. 2017; 17:36.

Kikuchi A, Kawada H, Iwaki Y, Machida S, Tsuchiya T, Fukuda R, Hotta T.Measurement of rituximab concentration in the cerebrospinal fluid in CNS lymphoma Rinsho Ketsueki. 2004; 45:1255-1257.

Komori M, Lin YC, Cortese I, Blake A, Ohayon J, Cherup J, Maric D, Kosa P, Wu T, Bielekova B. Insufficient disease inhibition by intrathecal rituximab in progressive multiple sclerosis. Ann Clin Transl Neurol. 2016; 3:166-179.

Klimatcheva E, Pandina T, Reilly C, Torno S, Bussler H, Scrivens M, Jonason A, Mallow C, Doherty M, Paris M, Smith ES, Zauderer M. CXCL13 antibody for the treatment of autoimmune disorders. BMC Immunol. 2015; 16:6.

Krishnan C, Kaplin AI, Brodsky RA, Drachman DB, Jones RJ, Pham DL, Richert ND, Pardo CA, Yousem DM, Hammond E, Quigg M, Trecker C, McArthur JC, Nath A, Greenberg BM, Calabresi PA, Kerr DA. Reduction of disease activity and disability with high-dose cyclophosphamide in patients with aggressive multiple sclerosis. Arch Neurol. 2008; 65:1044-1051.

La Mantia L, Milanese C, Mascoli N, D'Amico R, Weinstock-Guttman B. Cyclophosphamide for multiple sclerosis. Cochrane Database Syst Rev. 2007; (1):CD002819.

Lublin FD. New multiple sclerosis phenotypic classification. Eur Neurol. 2014; 72 Suppl 1:1-5.

Macallan DC, Asquith B, Irvine AJ, Wallace DL, Worth A, Ghattas H, Zhang Y, Griffin GE, Tough DF, Beverley PC Measurement and modeling of human T cell kinetics. Eur J Immunol. 2003 $33: 2316-2326$.

Macallan DC, Wallace DL. Zhang Y, Ghaftas H, Asquith B, de Lara C, Worth A, Panayiotakopoulos Griffn GE, Tough DF, Beverley PCL. B-cell kinetics in humans: rapid turnover of peripheral blood memory cells Blood. 2005; 105: 3633-3640

Mackay F, Schneider P, Rennery P, Browning J BAFF and APRIL: a tutorial on B cell survival. Ann Review Immunol 2003; 21:231-264.

Maria Silk \& Eric Nantz Efficacy and Safety of Tabalumab in Patients with Relapsing-Remitting Multiple Sclerosis: A Randomized, Double-Blind, Placebo-Controlled Study Neurology 2018; 90 (15 Suppl). P3.397. 
Martinelli Boneschi F, Vacchi L, Rovaris M, Capra R, Comi G. Mitoxantrone for multiple sclerosis. Cochrane Database Syst Rev. 2013; (5):CD002127

Michel L, Vukusic S, De Seze J, Ducray F, Ongagna JC, Lefrère F, Jacq-Foucher M, Confavreux C, Wiertlewski S, Laplaud DA. Mycophenolate mofetil in multiple sclerosis: a multicentre retrospective study on 344 patients. J Neurol Neurosurg Psychiatry. 2014; 85:279-283.

Minagawa $\mathrm{H}$, Takenaka A, Itoyama $\mathrm{Y}$, Mori R. Experimental allergic encephalomyelitis in the Lewis rat. A model of predictable relapse by cyclophosphamide. J Neurol Sci. 1987; 78:225-235.

Montalban X, Hauser SL, Kappos L, Arnold DL, Bar-Or A, Comi G, de Seze J, Giovannoni G, Hartung HP, Hemmer B, Lublin F, Rammohan KW, Selmaj K, Traboulsee A, Sauter A, Masterman D, Fontoura P, Belachew S, Garren H, Mairon N, Chin P, Wolinsky JS; ORATORIO Clinical Investigators. Ocrelizumab versus placebo in primary progressive multiple sclerosis. $\mathrm{N}$ Engl J Med. 2017; 376:209-220

Montalban X, Arnold DL, Weber MS, Staikov I, Piasecka-Stryczynska K, Wilmer J, Martin EC, Dangond F, Syed S, Wolinsky JS. Placebo-controlled trial of an oral BTK inhibitor in multiple sclerosis. N Engl J Med 2019; doi: 10:1056/NEJMoa1901981 [Epub].

Mulder A, Heidt S, Vergunst M, Roelen DL, Claas FH.Proteasome inhibition profoundly affects activated human B cells. Transplantation. 2013; 95:1331-1337.

Mulero P, Midaglia L, Montalban X. Ocrelizumab: a new milestone in multiple sclerosis therapy. Ther Adv Neurol Disord. 2018;11:1756286418773025.

Myers LW, Ellison GW, Merrill JE, El Hajjar A, St Pierre B, Hijazin M, Leake BD, Bentson JR, Nuwer MR, Tourtellotte WW, Davis $P$, Granger D, Fahey JL. Pentoxifylline is not a promising treatment for multiple sclerosis in progression phase. Neurology. 1998; 51:1483-486.

Nash RA, Bowen JD, McSweeney PA, Pavletic SZ, Maravilla KR, Park MS, Storek J, Sullivan KM, Al-Omaishi J, Corboy JR, DiPersio J, Georges GE, Gooley TA, Holmberg LA, LeMaistre CF, Ryan K, Openshaw H, Sunderhaus J, Storb R, Zunt J, Kraft GH. High-dose immunosuppressive therapy and autologous peripheral blood stem cell transplantation for severe multiple sclerosis. Blood. 2003; 102:2364-2372

O'Neill JK, Baker D, Davison AN, Maggon KK, Jaffee BD, Turk JL. Therapy of chronic relapsing experimental allergic encephalomyelitis and the role of the blood-brain barrier: elucidation by the action of Brequinar sodium. J Neuroimmunol. 1992; 38:53-62. 
Openshaw H, Lund BT, Kashyap A, Atkinson R, Sniecinski I, Weiner LP, Forman S. Peripheral blood stem cell transplantation in multiple sclerosis with busulfan and cyclophosphamide conditioning: report of toxicity and immunological monitoring. Biol Blood Marrow Transplant. $2000 ; 6(5 A): 563-75$.

Pal Singh S, Dammeijer F, Hendriks RW. Role of Bruton's tyrosine kinase in B cells and malignancies. Mol Cancer. 2018; 17:57

Paulino LRFM, Cunha EV, Barbalho Silva AW, Souza GB, Lopes EPF, Donato MAM, Peixoto CA, Matos-Brito BG, van den Hurk R, Silva JRV. Effects of tumour necrosis factor-alpha and interleukin-1 beta on in vitro development of bovine secondary follicles. Reprod Domest Anim. 2018; 53:997-1005.

Pender MP, Burrows SR Epstein-Barr virus and multiple sclerosis: potential opportunities for immunotherapy. Clin Transl Immunology. 2014; 3:e27

Pender MP, Csurhes PA, Smith C, Douglas NL, Neller MA, Beagley L, Rehan S, Hopkins TJ, Thompson KM, Blum S, Green KA, Ioannides ZA, Coulthard A, Hooper KD, Burrows SR, Khanna R. Safety and clinical improvement in a phase I trial of autologous Epstein-Barr virus-specific $T$ cell therapy in patients with progressive multiple sclerosis. Mult Scle J. 2017; 23 (S3):401

Perales MA, Kebriaei P, Kean LS, Sadelain M.Reprint of: building a safer and faster car: seatbelts, airbags, and CRISPR. Biol Blood Marrow Transplant. 2018; 24(3S):S15-S19.

Pryce G, Baker D. Oligoclonal bands in multiple sclerosis; Functional significance and therapeutic implications. Does the specificity matter? Mult Scler Relat Disord. 2018; 25:131-137

Ramsköld D, Parodis I, Lakshmikanth T, Sippl N, Khademi M, Chen Y, Zickert A, Mikeš J, Achour A, Amara K, Piehl F, Brodin P, Gunnarsson I, Malmström V. B cell alterations during BAFF inhibition with belimumab in SLE. EBioMedicine. 2019; 40:517-527.

Rejdak C, Stelmasiak Z, Grieb P. Cladribine induces long lasting oligoclonal bans disappearance in relapsing multiple sclerosis patients: 10 year observational study. Mult Scler Rel Disord $2018 ; 27: 117-120$

Rice GP, Filippi M, Comi G. Cladribine and progressive MS: clinical and MRI outcomes of a multicenter controlled trial. Cladribine MRI Study Group. Neurology. 2000; 54:1145-1155.

Robak P, Robak T. management of multiple myeloma with second-generation antibody-drug conjugates. BioDrugs. 2016; 30:87-93. 
Robak P, Robak T. Novel synthetic drugs currently in clinical development for chronic lymphocytic leukemia. Expert Opin Investig Drugs. 2017; 26:1249-1265

Ruella $\mathrm{M}$, June $\mathrm{CH}$.Chimeric antigen receptor T cells for $\mathrm{B}$ cell neoplasms: Choose the right CAR for you. Curr Hematol Malig Rep. 2016; 11:368-384.

Sabatino JJ, Zamvil SS, Hauser SL. B-cell therapies in multiple sclerosis. Cold Spring Harb Perspect Med. 2018. pii: a032037.

Saiz A, Carreras E, Berenguer J, Yagüe J, Martínez C, Marín P, Rovira M, Pujol T, Arbizu T, Graus F. MRI and CSF oligoclonal bands after autologous hematopoietic stem cell transplantation in MS. Neurology. 2001; 56:1084-1089.

San Segundo D, Ballesteros MA, Mons R, San Martín M, Zurbano F, Miñambres E, López-Hoyos $M$. Study of B-cell subpopulations in lung transplant recipients with posttransplant infection. Transplant Proc. 2012; 44:2676-2678.

Schattling B, Engler JB, Volkmann C, Rothammer N, Woo MS, Petersen M, Winkler I, Kaufmann M, Rosenkranz SC, Fejtova A, Thomas U, Bose A, Bauer S, Träger S, Miller KK, Brück W, Duncan KE, Salinas G, Soba P, Gundelfinger ED, Merkler D, Friese MA. Bassoon proteinopathy drives neurodegeneration in multiple sclerosis. Nat Neurosci. 2019; 22:887-896.

Schenkein D. Proteasome inhibitors in the treatment of B-cell malignancies.Clin Lymphoma. 2002; 3:49-55.

Schönfeld K, Zuber C, Pinkas J, Häder T, Bernöster K, Uherek C. Indatuximab ravtansine (BT062) combination treatment in multiple myeloma: pre-clinical studies. J Hematol Oncol. 2017; 10:13.

Sefia E, Pryce G, Meier UC, Giovannoni G, Baker D. Depletion of CD20 B cells fails to inhibit relapsing mouse experimental autoimmune encephalomyelitis. Mult Scler Relat Disord 2017; 14:46-50.

Sergott RC, Bennett JL, Rieckmann P, Montalban X, Mikol D, Freudensprung U, Plitz T, van Beek J; ATON Trial Group. ATON: results from a Phase II randomized trial of the B-cell-targeting agent atacicept in patients with optic neuritis. J Neurol Sci. 2015; 351:174-178.

Sipe JC, Romine JS, Koziol JA, McMillan R, Zyroff J, Beutler E. Cladribine in treatment of chronic progressive multiple sclerosis.Lancet. $1994 ;$ 344:9-13.

Sommer N, Löschmann PA, Northoff GH, Weller M, Steinbrecher A, Steinbach JP, Lichtenfels R, Meyermann R, Riethmüller A, Fontana A, Dichgans J, Martin R. The antidepressant rolipram 
suppresses cytokine production and prevents autoimmune encephalomyelitis. Nat Med. 1995; $1: 244-248$.

Storek J, Zhao Z, Lin E, Berger T, McSweeney PA, Nash RA, Akatsuka Y, Metcalf MD, Lu H, Kalina T, Reindl M, Storb R, Hansen JA, Sullivan KM, Kraft GH, Furst DE, Maloney DG. Recovery from and consequences of severe iatrogenic lymphopenia (induced to treat autoimmune diseases). Clin Immunol. 2004;113:285-98.

Studer V, Rossi S, Motta C, Buttari F, Centonze D. Peripheral B cell depletion and central proinflammatory cytokine reduction following repeated intrathecal administration of rituximab in progressive Multiple Sclerosis. J Neuroimmunol. 2014; 276:229-231.

Stüve O, Cepok S, Elias B, Saleh A, Hartung HP, Hemmer B, Kieseier B. Clinical stabilization and effective $\mathrm{B}$-lymphocyte depletion in the cerebrospinal fluid and peripheral blood of a patient with fulminant relapsing-remitting multiple sclerosis. Arch Neurol 2005;62:1620-1623.

Tillman BF, Pauff JM, Satyanarayana G, Talbott M, Warner JL. Systematic review of infectious events with the Bruton tyrosine kinase inhibitor ibrutinib in the treatment of hematologic malignancies. Eur J Haematol. 2018;100:325-334.

Topping J, Dobson R, Lapin S, Maslyanskiy A, Kropshofer H, Leppert D, Giovannoni G, Evdoshenko E.The effects of intrathecal rituximab on biomarkers in multiple sclerosis. Mult Scler Relat Disord. $2016 ; 6: 49-53$.

Tran JQ, Rana J, Barkhof F, Melamed I, Gevorkyan H, Wattjes MP, de Jong R, Brosofsky K, Ray S, Xu L, Zhao J, Parr E, Cadavid D.Randomized phase I trials of the safety/tolerability of antiLINGO-1 monoclonal antibody BIIB033. Neurol Neuroimmunol Neuroinflamm. 2014; 1:e18.

van Hoppe S, Rood JJM, Buil L, Wagenaar E, Sparidans RW, Beijnen JH, Schinkel AH. PGlycoprotein (MDR1/ABCB1) Restricts Brain Penetration of the Bruton's Tyrosine Kinase Inhibitor Ibrutinib, While Cytochrome P450-3A (CYP3A) Limits Its Oral Bioavailability. Mol Pharm. 2018; 15:5124-5134.

Wu J, Liu C, Tsui ST, Liu D. Second-generation inhibitors of Bruton tyrosine kinase. J Hematol Oncol. 2016; 9:80.

Xiao Y, Huang J, Luo $\mathrm{H}$, Wang J. Mycophenolate mofetil for relapsing-remitting multiple sclerosis.Cochrane Database Syst Rev. 2014;(2):CD01024

Zhang WY, Wang Y, Guo YL, Dai HR, Yang QM, Zhang YJ, Zhang Y, Chen MX, Wang CM, Feng KC, Li SX, Liu Y, Shi FX, Luo C, Han WD.Treatment of CD20-directed Chimeric Antigen Receptor- 
modified T cells in patients with relapsed or refractory B-cell non-Hodgkin lymphoma: an early phase IIa trial report. Signal Transduct Target Ther. 2016;1:16002.

Zhang WY, Liu Y, Wang Y, Wang CM, Yang QM, Zhu HL, Han WD. Long-term safety and efficacy of CART-20 cells in patients with refractory or relapsed B-cell non-Hodgkin lymphoma: 5-years follow-up results of the phase I and IIa trials. Signal Transduct Target Ther. 2017 2:17054

Zhao L, Jiang $Z$, Jiang $Y$, Ma N, Wang $K$, Zhang $Y$. Changes in immune cell frequencies after cyclophosphamide or mycophenolate mofetil treatments in patients with systemic lupus erythematosus. Clin Rheumatol. 2012; 31:951-959. 
FIGURE 1. Targeting domains for control B cell activity during multiple sclerosis.

Agents target plasma cells (blue) and/or B cell lineage cells (pink) cells and/or non-B cells (transparent), which are either quiescent (Dots) or dividing (Hatch). These can be targeted either in the periphery or within the periphery and central nervous system (Grey). Immunosuppressive agents that may be of value are shown, although their precise positioning is for illustrative purpose and can vary depending on the pharmacokinetic properties of the agents. Low activity against plasma cells is based on deoxycytosine levels and may not reflect events occurring in MS. BTKi Bruton's tyrosine kinase. Pi proteasome inhibitor, CY cyclophosphamide, CAR Chimeric antigen receptor.

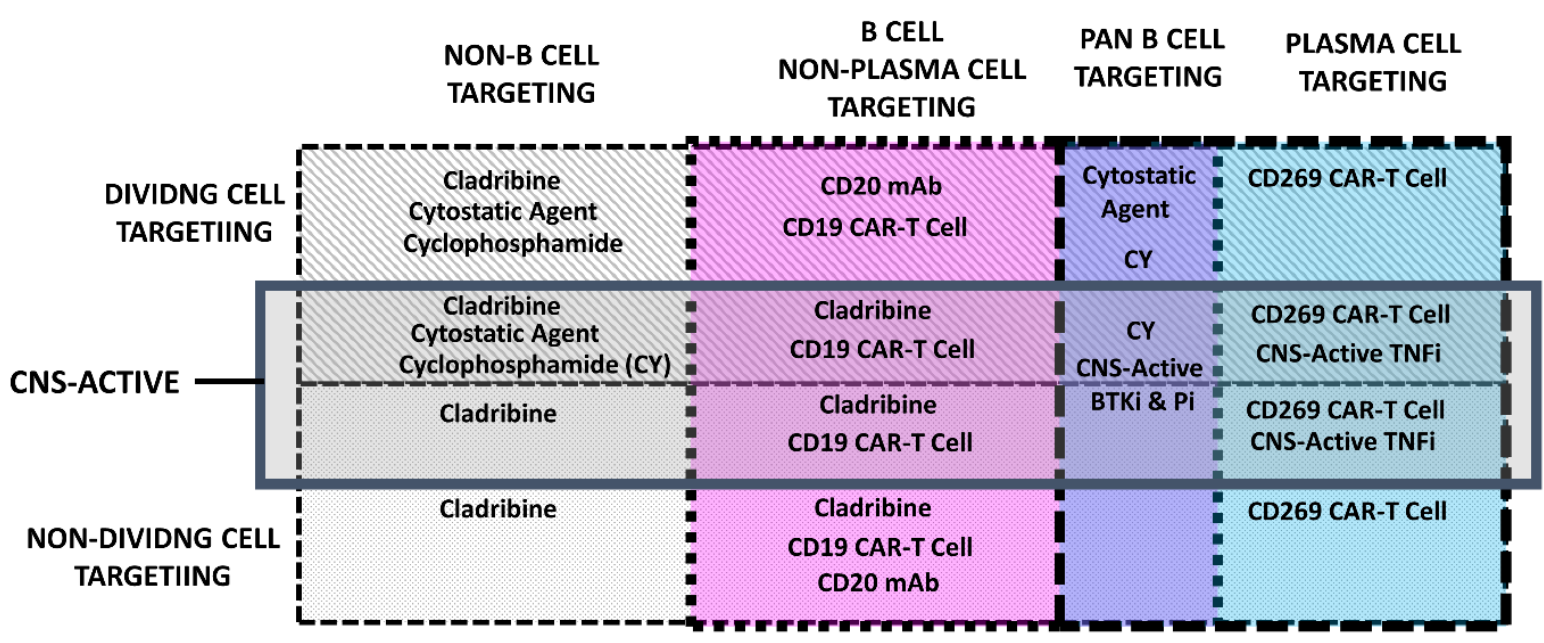

